\title{
The Correlation Between Vocabulary Mastery And Students' Ability In Arranging Random Words Into Good Sentence of The 2014 / 2015 Ninth Year Students of SMP Negeri 2 Stabat.
}

\author{
Sylvia Faska Bangun \\ SMP N.2 Stabat \\ Sylviafaska848@gmail.com
}

\begin{abstract}
The objective of the study is to find out correlation between vocabulary mastery and students' ability in arranging random word into good sentence of the 2014/2015 ninth year students of SMP Negeri 2 Stabat.The population of the study was the 2014/ 2015 the ninth year students of SMP Negeri 2 Stabat, totaling about 199 students. It was taken $20 \%$ from 199 students. It is 40 of them randomly as the sample of the research.This research was conducted by applying the correlationaldesign. The reliability of the test is counted by using Pearson Product Moment formula. The instrument was used to collect the data were multiple choicetest consisting of 20 items and essay test consisting of 20 items. Then the writer checked and gave score for both tests. The scores then were displayed in tables. After the data had been collected and analyzed, the findings showed that the value of $t_{\text {observed }}$ that is 0.50 is higher than the value of the $t_{\text {table }}$. It means that the test substantially high.This finding proves the hypothesis that the vocabulary mastery significantly correlates to students' ability in arranging random word into good sentence of the 2014/2015 ninth years students of SMP Negeri 2 Stabat.
\end{abstract} Key words : Correlational Research, Vocabulary Mastery and Arranging Random Words into Good
Sentence

\section{Background of The Study}

Language is surely the most important tool of communication. People used language to express their ideas, thought, and feeling either in spoken or written mood. It means that language is used as primary means of communication in society.

According Algeo a language is a system of conventional vocal signs by means of which human beings communicate. This definition has several important terms, each of which is examined in some detail. Those terms are system, signs, vocal, conventional, human, communicate. Language plays an important role in human's life. The people cannot survive without speaking a language, because it is mean of communication with one another to fulfill their need. We can also say that language cannot separate from human being.

English is one of languages as a foreign language. It has become an important language in the world and it has been widely used in school, government and businesses. Therefore, it is one of the subjects for junior high school students, senior high school and university. English language is taught in many countries in the world. Some countries take English as their foreign language and the other take it as their second language, but especially for some countries take it as their native language.

From this explanation above the writer understands that grammar is the rules in a language for changing the form words and joining them into sentences. Because of these English cannot separate with grammar. In other word, the leaner can communicate with others if they study mastering English vocabulary and grammar. This means, the learner not only able to spell or pronounce it, but also she/he should be able to 
differentiate its category and meaning when applying it into grammatically right sentence. In addition to this, the learner is able to express it orally as well.

Based on the description above, the writer chooses the title of the research as The Correlation between Vocabulary Mastery and Students' Ability in Arranging Random Words into Good Sentence of the 2014 / 2015 Ninth Year Students of SMP Negeri 2 Stabat.

Teaching of vocabulary is not easy to do because the English teacher should teach vocabulary English first rather than other aspects of language, such as grammar, speaking, reading and writing. If students know more vocabulary, it will be easier for them to learn other aspects of the English language. In this study the writer presents how to teach vocabulary to students so that they can help solve the problem in learning the English language. Students who have enough vocabulary are able to make sentences easily, especially in terms of preparing a random word in to a correct sentence. So that students can communicate or speak in English.

Random word is a form of exercise that is given to the student to determine the ability or mastery of the vocabulary of the students. Students' ability to arrange the words into good sentence that shows the true mastery of the vocabulary of the students. Therefore, mastery vocabulary concerned with setting up random words into acorrect sentence. Students who do not have a lot of vocabulary will get into trouble when putting together random words in to a correct sentence. In this study the writer presents also how to learn random words arranged into sentences is true that students are easier to learn and understand this lesson.

\section{Research Design}

This study is a correlational research. The writer applied the correlational research design. In this design, the writer will use the correlational statistical test to describe and measure the degree of relationship between two variables namely vocabulary mastery and students' ability in arranging random words into good sentence of grade IX students at SMP Negeri 2 Stabat in 2014/2015 academic year. The relationship between two variables namely vocabulary mastery and students' ability in arranging random words into good sentence can be drawn as follows:

$\mathrm{X} \longrightarrow \mathrm{Y}$

vocabulary mastery students' ability in arranging random words into good sentence.

This figure shows that $\mathrm{X}$ variable (vocabulary mastery) has a correlation to $\mathrm{Y}$ variable (students' ability in arranging random words into good sentence).

\section{The Population and Sample}

Arikunto said, "populasi adalah seluruh unsur-unsur dari penelitian". The populations of this study are the 2014/2015 Ninth Year Students of SMP Negeri 2 Stabat. There are five classes of the ninth year grade consisting of 199 students which is showed on table 1

Table 1. The Number of Population

\begin{tabular}{ccc}
\hline NO & Class & Students \\
\hline 1 & IX.1 & 40 \\
2 & IX.2 & 38 \\
3 & IX.3 & 42 \\
4 & IX.4 & 39 \\
5 & IX.5 & 40 \\
\hline & TOTAL & $\mathbf{1 9 9}$ \\
\hline
\end{tabular}

There are five classes of the ninth year grade consisting of 199 students. Because the population of ninth year students is more than 100 students, the writer decided to take $20 \%$ from 199 students. It is 40 of them randomly as the sample of the research. The consideration of taking such number of sample is based on what Arikunto states that if the subjects are large or more than 100, the sample can be $10-15 \%$, or $20-25 \%$, or more depending on the capability of the researcher. 


\section{The Variables of the Study}

Theoretically, any two quantitative variables can be correlated as long as we have scores on these variables from the same participants. Correlational research seeks to determine the degree of relationship between two or more variables.

In this study, there are two variables which are correlated, namely vocabulary mastery and students' ability in arranging random words into good sentence of grade ninth students at SMP Negeri 2 Stabat in 2014/2015 academic year. The vocabulary mastery refers to the students' competence in understanding and using English words appropriately. Students' ability in arranging random words into good sentence means the ability of students to make the right sentence based on the structure in arranging random words into good sentence.

\section{The Instrument of the Study}

Any study needs data to support the finding of the study. The data of this study were gained through the instrument of collecting data. The instrument was by giving to the students. There are two tests which were distributed to the students based on the data needed. The data on vocabulary mastery were obtained from multiple choices test consisting of 20 items, while the data on the students' ability in arranging random words into good sentence was achieved from the essay test consisting of 20 sentences.

In scoring the students' answer for both test, the writer used the following formula:

$$
\frac{\text { Correct Answer }}{\text { Total number of question }} x 100
$$

\section{The Techniques of Data Analysis}

After the students' answer sheet had been collected, then the writer checked and gave score for both tests. The scores then were displayed in tables.Since the objective of the study is to find out correlation between vocabulary mastery and students' ability in arranging random word into good sentence, therefore the data found were used to seek for the correlation between two variables. In this case, the Pearson Product Moment was applied to calculate the correlation coefficient.

The formula used in finding the correlation coefficient is as follow:

$$
\begin{aligned}
& \mathrm{r}_{\mathrm{xy}}=\frac{\left(N \cdot\left(\sum \mathrm{XY}\right)\right)-\left(\left(\sum \mathrm{X}\right)\left(\sum \mathrm{Y}\right)\right)}{\sqrt{\left.\left.\left(\left(N \cdot \Sigma \mathrm{X}^{2}\right)-\left(\sum \mathrm{X}\right)^{2}\right)\right)\left(\left(\left(N \cdot \Sigma \mathrm{Y}^{2}\right)\right)-\left(\sum \mathrm{Y}\right)^{2}\right)\right)}} \\
& \text { In which: } \mathrm{N}=\text { the number of samples } \\
& \sum X=\text { sum of } X \text { scores of Vocabulary Mastery } \\
& \sum Y=\text { sum of } Y \text { scores of Students' Ability in Arranging Random Word into Good } \\
& \text { Sentence. } \\
& \sum X^{2}=\text { sum of the squared } \mathrm{X} \text { scores of Vocabulary Mastery } \\
& \sum Y^{2}=\text { sum of the squared } \mathrm{Y} \text { scores of Students' Ability in Arranging Random Word } \\
& \text { into Good Sentence. } \\
& \sum X Y=\text { sum of the products of paired } \mathrm{X} \text { and } \mathrm{Y} \text { scores. }
\end{aligned}
$$

\section{Data Analysis}

The data on vocabulary mastery and students' ability in arranging random words into good sentence were obtained through multiple choices test and essay test were given to the students. After the giving the score on both variables, then the writer put the scores in tables.

\section{The Score of Vocabulary Mastery}

In order to get the data on Vocabulary Mastery, the writer applied Multiple Choice test. Based on the table, it was found that the Mean was 73.75. The highest score of students' ability in arranging random words into good sentence was 80 while the lowest was 65 . The Correlation between Vocabulary Mastery and Students' Ability in Arranging Random Words into Good Sentence Score.To see the correlation between two 
Journal of Applied Linguistics (JoAL), Vol. 1 No. 1, July 2021. e-ISSN 2809-1922, p-ISSN 2809-1914

variables, namely the Vocabulary Mastery and Students' Ability in Arranging Random Word into Good Sentence, the writer needed the following data on table 2.

Table 2. The Students' Scores on Vocabulary Mastery(X) and Students' Ability in Arranging Random Word into Good Sentence(Y)

\begin{tabular}{|c|c|c|c|c|c|c|}
\hline No. & Name & $\mathbf{X}$ & $\mathbf{Y}$ & $\mathbf{X}^{2}$ & $\mathbf{Y}^{2}$ & XY \\
\hline 1 & $\mathrm{AP}$ & 50 & 70 & 2500 & 4900 & 3500 \\
\hline 2 & AA & 65 & 80 & 4225 & 6400 & 5200 \\
\hline 3 & AS & 55 & 70 & 3025 & 4900 & 3850 \\
\hline 4 & $\mathrm{AR}$ & 65 & 75 & 4225 & 5625 & 4875 \\
\hline 5 & BL & 70 & 75 & 4900 & 5625 & 5250 \\
\hline 6 & CIS & 60 & 70 & 3600 & 4900 & 4200 \\
\hline 7 & DM & 65 & 65 & 4225 & 4225 & 4225 \\
\hline 8 & DA & 75 & 80 & 5625 & 6400 & 6000 \\
\hline 9 & ED & 65 & 80 & 4225 & 6400 & 5200 \\
\hline 10 & EK & 60 & 80 & 3600 & 6400 & 4800 \\
\hline 11 & EN & 55 & 65 & 3025 & 4225 & 3575 \\
\hline 12 & ET & 65 & 70 & 4225 & 4900 & 4550 \\
\hline 13 & FA & 65 & 65 & 4225 & 4225 & 4225 \\
\hline 14 & FR & 70 & 75 & 4900 & 5625 & 5250 \\
\hline 15 & FA & 65 & 80 & 4225 & 6400 & 5200 \\
\hline 16 & FR & 65 & 75 & 4225 & 5625 & 4875 \\
\hline 17 & FK & 65 & 75 & 4225 & 5625 & 4875 \\
\hline 18 & $\mathrm{HF}$ & 65 & 80 & 4225 & 6400 & 5200 \\
\hline 19 & HM & 65 & 75 & 4225 & 5625 & 4875 \\
\hline 20 & HI & 60 & 80 & 3600 & 6400 & 4800 \\
\hline 21 & ID & 60 & 75 & 3600 & 5625 & 4500 \\
\hline 22 & IP & 55 & 80 & 3025 & 6400 & 4400 \\
\hline 23 & $\mathrm{KH}$ & 60 & 75 & 3600 & 5625 & 4500 \\
\hline 24 & MA & 65 & 80 & 4225 & 6400 & 5200 \\
\hline 25 & MA & 65 & 75 & 4225 & 5625 & 4875 \\
\hline 26 & MF & 70 & 80 & 4900 & 6400 & 5600 \\
\hline 27 & MH & 45 & 70 & 2025 & 4900 & 3150 \\
\hline 28 & MK & 50 & 65 & 2500 & 4225 & 3250 \\
\hline 28 & MKF & 40 & 75 & 1600 & 5625 & 3000 \\
\hline 30 & PA & 50 & 65 & 2500 & 4225 & 3250 \\
\hline 31 & RA & 65 & 75 & 4225 & 5625 & 4875 \\
\hline 32 & RR & 65 & 80 & 4225 & 6400 & 5200 \\
\hline 33 & RA & 70 & 75 & 4900 & 5625 & 5250 \\
\hline 34 & RAK & 70 & 80 & 4900 & 6400 & 5600 \\
\hline 35 & RA & 65 & 80 & 4225 & 6400 & 5200 \\
\hline 36 & SA & 60 & 65 & 3600 & 4225 & 3900 \\
\hline 37 & WH & 55 & 70 & 3025 & 4900 & 3850 \\
\hline 38 & YN & 40 & 65 & 1600 & 4225 & 2600 \\
\hline 39 & $\mathrm{ZF}$ & 50 & 70 & 2500 & 4900 & 3500 \\
\hline \multirow[t]{2}{*}{40} & ZA & 60 & 65 & 3600 & 4225 & 3900 \\
\hline & Total & 2430 & 2950 & 150250 & 218800 & 180125 \\
\hline
\end{tabular}

From table 2 above it is found that:

$\mathrm{N} \quad=40$

Published by English Lecturers and Teachers Association (ELTA)

Copyright (C) 2021, authors 


$$
\begin{aligned}
\Sigma X Y & =180125 \\
\Sigma X & =2430 \\
\Sigma Y & =2950 \\
\Sigma X^{2} & =150250 \\
\Sigma Y^{2} & =218800
\end{aligned}
$$

\section{Research Finding}

The data which were found from the test and tabulated in tables then were analyzed. This analysis of data was needed as the objective of the study is to find out correlation between vocabulary mastery and students' ability in arranging random word into good sentence. The writer used the scores of both test to analyze the correlation between them.

The writer applied Pearson's Product Moment formula to find out correlation between vocabulary mastery and students' ability in arranging random word into good sentence. The formula was shown below:

$$
\mathrm{r}_{\mathrm{xy}}=\frac{\left(N \cdot\left(\sum \mathrm{XY}\right)\right)-\left(\left(\sum \mathrm{X}\right)(\Sigma \mathrm{Y})\right)}{\sqrt{\left.\left.\left(\left(N \cdot \Sigma \mathrm{X}^{2}\right)-(\Sigma \mathrm{X})^{2}\right)\right)\left(\left(\left(N \cdot \Sigma \mathrm{Y}^{2}\right)\right)-\left(\sum \mathrm{Y}\right)^{2}\right)\right)}}
$$

By using the formula, correlation coefficient of both variables can be calculated as in the following:

$$
\begin{aligned}
r_{x y} & =\frac{(40(180125))-((2430)(2950))}{\sqrt{\left.\left.\left((40 \times 150250)-(2430)^{2}\right)\right)\left(((40 \times 218800))-(2950)^{2}\right)\right)}} \\
r_{x y} & =\frac{(7205000)-(7168500)}{\sqrt{((6010000)-(5904900))((8752000))-(8702500))}} \\
r_{x y} & =\frac{36500}{\sqrt{(105100)(49500)}} \\
r_{x y} & =\frac{36500}{\sqrt{5202450000}} \\
r_{x y} & =\frac{36500}{72128.011202} \\
r_{x y} & =0.50
\end{aligned}
$$

From the calculation by using Pearson Product moment formula above, it was got that the correlation coefficient between two variables was 0.50 . Then, to interpret the strength of the correlation coefficient, the writer used David's interpretation strength of correlation coefficient which is explained on table 3

Table 3 Interpreting strength of Correlation Coefficients

\begin{tabular}{cc}
\hline Correlation coefficient & Strength \\
\hline $0.01-0.09$ & Very small \\
$0.10-0.29$ & Small, low to moderate \\
$0.30-0.49$ & Moderate, medium \\
$0.50-0.69$ & Substantially high \\
$0.70-0.89$ & High, strong \\
$0.90-1.00$ & Very high to perfect \\
\hline
\end{tabular}

From the table 4.4, it could be seen that the correlation coefficient of 0.50 was located between 0.50 - 0.69. it means that the degree of the correlation was considered as a substantially high correlation.

\section{The Hypothesis testing}

The hypothesis of the study is that there is significant correlation between vocabulary mastery and students' ability in arranging random word into good sentence of the 2014/2015 ninth years students of SMP 
Negeri 2 Stabat. This hypothesis is still a tentative answer to the problem and needs to be proved or tested. To test the hypothesis, correlation coefficient of 0.50 is consulted with the critical value of the correlation with degree of freedom $(d f)=40-2=38$. The critical value with this $d f$ is 0.304 for the 0.05 level of significance. The result shows that $r$ value or the correlation coefficient got from the data analysis is higher than the critical value $(0.50>0.304)$ and the hypothesis of this study is accepted. Thus, the study proved that the vocabulary mastery significantly correlates to students' ability in arranging random word into good sentence of the 2014/2015 ninth years students of SMP Negeri 2 Stabat.

The data was shown on table 4 below:

Table 4 Critical values for Pearson correlation

\begin{tabular}{|c|c|c|c|c|}
\hline \multirow{4}{*}{$\begin{array}{c}\text { df }=\mathrm{N}-2 \\
(\mathrm{~N}=\text { number } \\
\text { of pairs })\end{array}$} & \multicolumn{4}{|c|}{ Level of significance for one-tailed test } \\
\hline & .05 & .025 & .01 & .005 \\
\hline & \multicolumn{4}{|c|}{ Level of significance for two-tailed test } \\
\hline & .10 & .05 & .02 & .01 \\
\hline 1 & .988 & .997 & .9995 & .9999 \\
\hline 2 & .900 & .950 & .980 & .990 \\
\hline 3 & .805 & .878 & .934 & .959 \\
\hline 4 & .729 & .811 & .882 & .917 \\
\hline 5 & .669 & .754 & .833 & .874 \\
\hline 6 & .622 & .707 & .789 & .834 \\
\hline 7 & .582 & .666 & .750 & .798 \\
\hline 8 & .549 & .632 & .716 & .765 \\
\hline 9 & .521 & .602 & .685 & .735 \\
\hline 10 & 497 & .576 & .658 & .708 \\
\hline 11 & 476 & .553 & .634 & .684 \\
\hline 12 & .458 & .532 & 612 & .661 \\
\hline 13 & 441 & .514 & .592 & .641 \\
\hline 14 & .426 & .497 & .574 & .628 \\
\hline 15 & .412 & .482 & .558 & .606 \\
\hline 16 & .400 & .468 & .542 & .590 \\
\hline 17 & .389 & .456 & .528 & .575 \\
\hline 18 & .378 & .444 & .516 & .561 \\
\hline 19 & .369 & .433 & .503 & .549 \\
\hline 20 & .360 & .423 & .492 & .537 \\
\hline 21 & .352 & .413 & .482 & .526 \\
\hline 22 & .344 & .404 & .472 & .515 \\
\hline 23 & .337 & .396 & .462 & .505 \\
\hline 24 & .330 & .388 & .453 & .495 \\
\hline 25 & .323 & .381 & .445 & .487 \\
\hline 26 & .317 & .374 & .437 & .479 \\
\hline 27 & .311 & .367 & .430 & .471 \\
\hline 28 & .306 & .361 & .423 & .463 \\
\hline 29 & .301 & .355 & .416 & .456 \\
\hline 30 & .296 & .349 & .409 & .449 \\
\hline 35 & .275 & .325 & .381 & .418 \\
\hline 40 & .257 & .304 & .358 & .393 \\
\hline 45 & .243 & .288 & .338 & .372 \\
\hline 50 & .231 & .273 & .322 & .354 \\
\hline 60 & .211 & .250 & .295 & .325 \\
\hline 70 & .195 & .232 & .274 & .302 \\
\hline 80 & .183 & .217 & .256 & .284 \\
\hline 90 & .173 & .205 & .242 & .267 \\
\hline
\end{tabular}

Published by English Lecturers and Teachers Association (ELTA)

Copyright (C) 2021, authors 


\begin{tabular}{lllll}
\hline 100 & .164 & .195 & .230 & .254 \\
\hline
\end{tabular}

\section{The Conclusion}

Having the result of data analysis and hypothesis testing, that the correlation coefficient got in this study is 0.50 higher than the critical value of correlation with $d f 38(0.50>0.304)$, the writer can make a conclusion that the hypothesis of this study is accepted. It means that There is significant correlation between vocabulary mastery and students' ability in arranging random word into good sentence of the 2014/2015 ninth year students of SMP Negeri 2 Stabat.

\section{REFERENCES}

Algeo,John.(2005). The Origins and Development of the English Language. Wadsworth: Cengage Learning. Arikunto, Suharsimi.(2006). Prosedur Penelitian. Jakarta: PT. Rineka Cipta.

Bacon. Allyn.(2003). Contemporary English Grammar. New Delhi: Book Palace.

De Vaus, Davit.(2005). Surveys in Social Research. New South Wales: Routledge.

Maba, Ghufron.(2009). Basic English Instruction for Beginners.Bandung: Yrama Widia.

Manser, Martin H.(2000). Oxford Learner's Pocket Dictionary. England: Longman.

Marguerite G. Lodico, et.al.(2010). Methods in Educational Research. San Francisco: Jose Bass.

Harmer, Jeremy.(2001). How to Teach English. England: Person Education Limited Edition.

Hornby.(2005). Oxford Learner's Dictionary. New York: Oxford University Press.

Richard, G. Lomax.(2007). An Introduction to Statistical Concepts.New Jersey: Lawrence Erlbaum Associates, Inc.

Rusmajadi, Jodin.(2010). Terampil Berbahasa Inggris. Jakarta: Indeks.

Sunarti.(2010). Teaching Vocabulary by Using Pictures to the Fifth Year Students of SDN 031 Samarinda Utara in Academic Year 2010/2011. Samarinda: Mulawarman University.

http://ltr.sagepub.com/content/12/3/329.abstract, accessed on 10 August 2014.

http://englishresources.com/vocabulary.php, accessed on 10 August 2014.

http://www.instructionaldesign.org/domains/language.html, accessed on 10 August 2014.

http://simple.wikipedia.org/wiki/Word_order, accessed on 11 August 2014

http://05128800.blogspot.com/2011/06/definition-of-vocabulary.html\#!, accessed on 10 August 2014.

http://en.wikipedia.org/wiki/Vocabulary, accessed on 10 August 2014

http://busyteacher.org/3687-how-to-teach-word-order.html, accessed on 11 August 2014

http://www.merriam-webster.com/dictionary/word\%20order, accessed on 11 August 2014

Published by English Lecturers and Teachers Association (ELTA)

Copyright (C) 2021, authors 